IT has been shown previously that cultured human venous and arterial endothelial cells (EC) bind C1q in a time- and dose-dependent manner. Cultured human endothelial cells express an average number of $5.2 \times 10^{5}$ binding sites/cell. In the present study the putative receptor for $\mathrm{C} 1 \mathrm{q}$ (C1qR) was isolated from the membranes of 1-5 $\times 10^{9}$ human umbilical cord EC by affinity chromatography on C1q-Sepharose. During isolation, C1qR was detected by its capacity to inhibit the 1ysis of EAC1q in C1q-deficient serum. The eluate from C1q-Sepharose was concentrated, dialysed and subjected to QAE-A50 chromatography and subsequently to gel filtration on HPLC-TSK 3000. C1qR filtered at an apparent molecular weight of $60 \mathrm{kDa}$. Purified C1qR exhibited an apparent molecular weight of $55-62 \mathrm{kDa}$ in the unreduced state and a molecular weight of $64-68 \mathrm{kDa}$ in reduced form. Two IgM monoclonal antibodies $(\mathrm{mAb}) \mathrm{D} 3$ and D5 were raised following immunization of mice with purified receptor preparations. Both monoclonal antibodies increased the binding of ${ }^{125} \mathrm{I}-\mathrm{C} 1 \mathrm{q}$ to endothelial cells but $\mathrm{F}\left(\mathrm{ab}^{\prime}\right)_{2}$ anti-C1qR $\mathrm{mAb}$ inhibited the binding of ${ }^{125} \mathrm{I}-\mathrm{C} 1 \mathrm{q}$ to $\mathrm{EC}$ in a dosedependent manner. The D3 mAb recognized a band of $54-60 \mathrm{kDa}$ in Western blots of membranes of human EC and polymorphonuclear leukocytes. Previously, the authors showed that $\mathrm{C1q}$ induces the binding of IgM-containing immune complexes to EC. Therefore, it was hypothesized that during a primary immune response generation of IgM-IC may occur, resulting in binding and activation of $\mathrm{C} 1$, dissociation of activated $\mathrm{C} 1$ by $\mathrm{C} 1$ inhibitor and subsequent interaction of IgM-IC bearing C1q with EC-C1qR.

Key words: Complement, C1q, C1q receptor, Endothelial cells, Immune complexes, Monoclonal antibodies

\section{Isolation and function of a human endothelial cell C1q receptor}

\author{
M. R. DahacA L. Dunn, R. van den Berg \\ Y. Muizert-de Lange, A. Gerritsen and \\ L. A. van Es
}

Department of Nephrology, University Hospital Leiden, P.O. Box 9600, building 1, C3-P, 2300 RC Leiden, The Netherlands

${ }^{\mathrm{CA}}$ Corresponding Author

\section{Introduction}

The endothelial cell layer represents a barrier between the circulation and the vessel wall, and may play an important role in processes which mediate inflammation. The role of the vascular endothelium in the deposition of immune complexes (IC) in vivo is not clear. Most IC are able to trigger receptor mediated activation of various cells such as monocytes and granulocytes. This may occur via Fc receptors alone or via Fc receptors in synergy with complement receptors. Receptors for the Fc $\gamma$ portion of $\operatorname{IgG}$ have been described on various cells, ${ }^{1}$ and more recently the authors have shown that rat liver endothelial cells express functional receptors for the $\mathrm{Fc} \gamma$ region of $\mathrm{IgG}$ in situ. ${ }^{2}$ Furthermore, receptors for the Fc $\gamma$ region of $\mathrm{IgG}$ and $\mathrm{C} 3 \mathrm{~b}$ were found on Herpes simplex virus (HSV)-infected umbilical cord venous endothelial cells. ${ }^{3}$ Later studies have established that these receptors are encoded by the viral genome. ${ }^{4,5}$ The first indication that another complement receptor was present on endothelial cells, namely a receptor for C1q, was obtained by Linder ${ }^{6}$ and further established by other. ${ }^{7}$ The authors have described previously that human umbilical cord venous and arterial EC express substantial numbers of $\mathrm{C} 1 \mathrm{qR} .{ }^{8}$ More insight into the binding of $\mathrm{C} 1 \mathrm{q}$ to a variety of somatic and cultured cells and further identification of a putative $\mathrm{C} 1 \mathrm{qR}$ has been obtained more recently. ${ }^{9-12}$ In the present study $\mathrm{C} 1 \mathrm{qR}$ was purified from the membranes of cultured umbilical cord EC and it appears to be closely related to $\mathrm{C} 1 \mathrm{q}$ receptors purified from peripheral blood leukocytes ${ }^{13-15}$ and platelets. ${ }^{16}$

\section{Materials and Methods}

Endothelial cell cultures: Human umbilical cord vein endothelial cells (HUVEC) were isolated and cultured as described. ${ }^{8,17}$ In short, umbilical cord veins were flushed with phosphate buffered saline and incubated with a collagenase solution $(1 \mathrm{mg} / \mathrm{ml}$, 
Sigma, St. Louis, MO) for $20 \mathrm{~min}$ at $37^{\circ} \mathrm{C}$. Cells were cultured on $1 \%$ gelatin treated plastic culture flasks (T75, Greiner) in M199 with Earls salts (Seromed, Biochrom KG, Berlin, Germany) supplemented with $20 \%$ heat inactivated normal human serum and endothelial cell growth factor ${ }^{18}$ isolated from bovine hypothalamus. Cells were subcultured after trypsinization by distributing them into three new culture flasks. For the isolation of $\mathrm{C} 1 \mathrm{qR}$ generally $1-5 \times 10^{9}$ HUVEC were used from passage 4-7. In most cases endothelial cells obtained from three to four umbilical cords were pooled. HUVEC were routinely examined by indirect immunofluorescence employing a rabbit polyclonal anti-human WF antibody (gift of Professor R. Bertina, Leiden).

Isolation of $\mathrm{C} 1 \mathrm{qR}$ was also performed from the membranes of the endothelial hybridoma cell line EAhy.926. This line was obtained by fusing human umbilical vein endothelial cells with the human cell line A549 (human lung carcinoma) and was maintained in culture as described previously. ${ }^{19}$

Solubilization of HUVEC and EAby.926: Confluent layers of cells were rinsed with sterile PBS, the cells detached subsequently by incubation for $30 \mathrm{~min}$ at $0^{\circ} \mathrm{C}$ in PBS containing $10 \mathrm{mM}$ EDTA, and washed three times by centrifugation at $150 \times \boldsymbol{g}$ and resuspension in ice-cold water containing $5 \mathrm{mM}$ EDTA. Usually, 1-5 × $10^{9}$ cells were resuspended in $5 \mathrm{ml}$ water, and frozen at $-80^{\circ} \mathrm{C}$. Thereafter the cells were frozen and thawed a total of five times. The resultant mixture was centrifuged for $10 \mathrm{~min}$ at $15000 \times \boldsymbol{g}$ and the pellet containing mainly cell membranes washed three times with ice-cold PBS containing $5 \mathrm{mM}$ EDTA. The washed cell membrane pellet was finally resuspended in $2 \mathrm{ml}$ lysis buffer composed of $5 \mathrm{mM}$ sodium phosphate, $5 \mathrm{mM}$ EDTA, $150 \mathrm{mM} \mathrm{NaCl}, 10 \mathrm{mM}$ EACA and $0.5 \mathrm{mM}$ PMSF, pH 7.5 and containing $1 \%$ nonidet $\mathrm{P} 40$. After incubation for $60 \mathrm{~min}$ at $37^{\circ} \mathrm{C}$ with vigorous shaking, the mixture was centrifuged for $20 \mathrm{~min}$ at $30000 \times \boldsymbol{g}$ and the supernatant dialysed against lysis buffer containing $0.1 \%$ NP40.

Purification of C1qR: Endothelial cell membrane lysates were loaded on a column of $4 \mathrm{ml}$ Sepharose-C1q equilibrated in PBS containing $0.5 \mathrm{mM}$ PMSF, $5 \mathrm{mM}$ EDTA and $0.1 \% \mathrm{NP} 40$, $\mathrm{pH}$ 7.5. C1q was isolated from pooled human serum as described previously ${ }^{20}$ and $3 \mathrm{mg}$ of $\mathrm{C} 1 \mathrm{q}$ was coupled to $1 \mathrm{ml}$ of packed Sepharose. After vigorous washing bound $\mathrm{C} 1 \mathrm{qR}$ was liberated from the column using $1 \mathrm{M} \mathrm{NaCl}$. Protein content in the fractions was measured by the Lowry method and conductivity was assessed at $4^{\circ} \mathrm{C}$. $\mathrm{C} 1 \mathrm{qR}$ was assayed in the fractions using a haemolytic assay. The fractions containing $\mathrm{C} 1 \mathrm{qR}$ activity were pooled, dialysed against $5 \mathrm{mM}$ PMSF and subjected to ion exchange chromatography on a $1.5 \times 10 \mathrm{~cm}$ QAE-A50 Sephadex column equilibrated in dialysis buffer. Bound activity was stripped from the column with dialysis buffer containing $0.65 \mathrm{M}$ $\mathrm{NaCl}$. C1qR activity was pooled, freeze dried, resuspended in $250 \mu \mathrm{l}$ PBS containing $5 \mathrm{mM}$ EDTA and $0.5 \mathrm{mM}$ PMSF and after filtration on millipore $0.2 \mu$ subjected to gel filtration on TSK 3000 HPLC. Fractions of $0.3 \mathrm{ml} / \mathrm{min}$ were collected and assessed for $\mathrm{C} 1 \mathrm{qR}$ activity.

Assay for C1qR baemolytic activity: Sheep erythrocytes (E) sensitized with optimal concentrations of rabbit IgG anti-E were prepared and incubated with a suboptimal concentration of $\mathrm{C} 1 \mathrm{q}$, and washed at $4^{\circ} \mathrm{C}$ with $\mathrm{GVB}^{2+}$. To assay for $\mathrm{C} 1 \mathrm{qR}$ haemolytic activity, tubes containing $1 \times 10^{7} \mathrm{EAC} 1 \mathrm{q}$ in $100 \mu \mathrm{l}$ $\mathrm{DGVB}^{++}$were incubated with dilutions of fractions from columns for $30 \mathrm{~min}$ at $0^{\circ} \mathrm{C}$ and thereafter $0.1 \mathrm{ml} \mathrm{C1q}$ deficient serum diluted $1 / 50$ in $\mathrm{DGVB}^{++}$was added to each tube followed by incubation for another $60 \mathrm{~min}$ at $37^{\circ} \mathrm{C}$. Percent haemolysis was determined following addition of $1.5 \mathrm{ml} 0.15 \mathrm{M} \mathrm{NaCl}$ and centrifugation. Appropriate controls for reagent blank and input were included in each assay. The amount of C1q chosen to prepare EAC1q was such that EAC1q in $\mathrm{C} 1 \mathrm{q}$ deficient serum caused approximately $60-70 \%$ lysis of the cells.

Radioiodination procedures: TSK 3000-HPLC-derived pools of $\mathrm{C} 1 \mathrm{qR}$ were iodinated using $100 \mu \mathrm{Ci} \mathrm{Na}{ }^{125} \mathrm{I}$ (Amersham) as described previously. ${ }^{21}$ Excess free ${ }^{125} \mathrm{I}$ was removed by passing the reaction mixture over a $0.5 \times 5 \mathrm{~cm}$ Dowex $1-\times 8$ column equilibrated in PBS containing 1\% glycerol and $0.05 \%$ NP40.

Surface iodination of intact HUVEC or purified $\mathrm{PMN}^{22}$ was performed with $1 \times 10^{7}$ cells in $1 \mathrm{ml}$ PBS at $22^{\circ} \mathrm{C}$ by addition of $0.5 \mathrm{mCi} \mathrm{Na}{ }^{125} \mathrm{I}, 60 \mu \mathrm{l}$ lactoperoxidase $(1 \mathrm{mg} / \mathrm{ml})$, and three sequential additions $\left(10 \mu \mathrm{l}\right.$ each) of $\mathrm{H}_{2} \mathrm{O}_{2}$ of $0.003 \%$ every 10-20 s. Thereafter the cells were washed three times by centrifugation and resuspension in PBS to remove free ${ }^{125} \mathrm{I}$, and finally solubilized in lysis buffer.

SDS-polyacrylamide gel electrophoresis (SDS-PAGE): SDS-PAGE was performed using 7.5\% polyacrylamide gels. ${ }^{23}$ Samples were mixed with an equal volume of $0.2 \mathrm{M}$ Tris, $2 \% \mathrm{SDS}, \mathrm{pH} 8.0$ with and without $10 \mathrm{mM} 2 \beta$-mercaptoethanol and boiled for $5 \mathrm{~min}$. Gels were stained with Coomassie brilliant blue, dried, and subjected to autoradiography using X-ray film.

Western blot analysis was performed as described previously. ${ }^{24}$ Five and $10 \mu \mathrm{g}$ samples of solubilized membranes were subjected to SDS-PAGE, blotted onto nitrocellulose, reacted with monoclonal 
antibodies or isotype controls, washed and bound antibodies reacted with biotinylated goat antimouse $\mathrm{Ig}$, followed by incubation with streptavidin alkaline phosphatase (Zymed Laboratories Inc.) for $1 \mathrm{~h}$, and detected with naphthol AS-MX phosphate (Sigma, St. Louis, MO) and Fast Red (Sigma) as substrate. Every incubation step was followed by a 15 min washing step in PBS-0.5\% Tween 20.

Monoclonal antibodies: Spleen cells were obtained by standard techniques from Balb/c mice immunized with three weekly injections of $50 \mu \mathrm{g}$ quantities of $\mathrm{C} 1 \mathrm{qR}$ emulsified in complete Freund's adjuvant. The spleen cells were fused with non-secreting SP 20 myeloma cells and the fused cells selected in hypoxanthine-aminopterin-thymidine medium. Culture supernatants of cell lines were screened by ELISA for reactivity with purified $\mathrm{C} 1 \mathrm{qR}$ from HUVEC. From each positive well, individual clones were prepared by adding $100 \mu \mathrm{l}$ culture medium containing 3 cells $/ \mathrm{ml}$ to microtitre plates. In this way two positive clones were selected (D3 and D5) for further analysis. Ascitis was prepared in Balb/c mice following injection of $1 \times 10^{6}$ cells per mouse. Limited proteolytic digestion of mouse IgM was carried out by incubation of $1 \mathrm{mg} / \mathrm{ml}$ solutions of D5 or control MoAb in $20 \mathrm{mM}$ Tris, $150 \mathrm{mM} \mathrm{NaCl}, 20 \mathrm{mM}$ cad2, pH 8 with $150 \mu \mathrm{g} / \mathrm{ml}$ diphenyl carbamyl chloride (DPCC, Sigma) treated trypsin (Sigma) for $5 \mathrm{~h}$ at $37^{\circ} \mathrm{C}$. Mercaptoethanol was added to $10 \mathrm{mM}$ and the solution incubated for $5 \mathrm{~min}$ at $37^{\circ} \mathrm{C}$, followed by $15 \mu \mathrm{g} / \mathrm{ml}$ trypsin inhibitor (Sigma) to stop the reaction and further incubated for $5 \mathrm{~min}$. Finally the mixture was made up to $50 \mathrm{mM}$ iodoacetamide and left at room temperature for $10 \mathrm{~min}$. After dialysis $7 \mathrm{~S}$ fragments of IgM were obtained by gel filtration on Sepharose 4B. The $7 \mathrm{~S}$ fragments were dialysed against sodium acetate buffer $\mathrm{pH} 3.8$ and treated with $1 \%$ pepsin $(\mathrm{w} / \mathrm{w})$ for $16 \mathrm{~h}$ at $37^{\circ} \mathrm{C}$ and the $\mathrm{F}\left(\mathrm{ab}^{\prime}\right)_{2}$ fragments recovered after gel filtration on Sephadex G150.

Binding studies: The binding of ${ }^{125} \mathrm{I}-\mathrm{C} 1 \mathrm{q}$ to $\mathrm{EC}$ was performed as described previously. ${ }^{8}$ To determine the effect of D3 and D5 on binding of ${ }^{125} \mathrm{I}-\mathrm{C} 1 \mathrm{q}$ to $\mathrm{EC}$, monolayers of $\mathrm{EC}$ in 48-well culture wells were incubated with $100 \mathrm{ng}{ }^{125} \mathrm{I}-\mathrm{C} 1 \mathrm{q}$ in RPMI-0.5\% BSA alone or in the presence of increasing concentrations of purified $\mathrm{F}\left(\mathrm{ab}^{\prime}\right)_{2}$ D3 or D5 monoclonal antibodies. As a control a nonspecific $\mathrm{F}\left(\mathrm{ab}^{\prime}\right)_{2}$ from mouse IgM monoclonal antibody was used. After incubation for $2 \mathrm{~h}$ at $4^{\circ} \mathrm{C}$, the wells were washed and cell bound radioactivity assessed following lysis of the cells with $100 \mu \mathrm{l} 1 \mathrm{~N} \mathrm{NaOH}$ for $1 \mathrm{~h}$.

\section{Results}

The fractionation of detergent solubilized endothelial cell membranes from HUVEC by

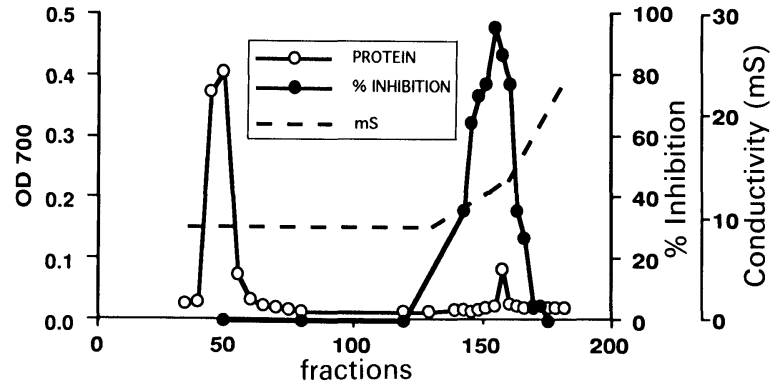

FIG. 1. Affinity chromatography of detergent solubilized endothelial cell membranes on Sepharose-C1q. Protein content $(\mathrm{O}-\mathrm{O})$, conductivity $(--)$ and $\mathrm{C} 1 \mathrm{q}-\mathrm{R}$ activity (-O) in the fractions is depicted. Fractions 148-162 were pooled for further purification on QAE-A50.

affinity chromatography on Sepharose-C1q is shown in Fig. 1. Most of the protein was found in the fall-through fractions, while only a small amount of protein emerged from the column between 11 and $14 \mathrm{mS}$. When the fractions from the column were tested in dilutions of $1: 10$ for $\mathrm{C} 1 \mathrm{qR}$ function all the inhibitory activity was found to be associated with the protein peak in the gradient. Fractions 148-162 were pooled, dialysed and fractionated further on a QAE-A50 Sephadex column (Fig. 2). Very little detectable protein was found in the fall-through fractions and more than $80 \%$ of $\mathrm{C} 1 \mathrm{qR}$ functional activity could be eluted from the QAE column with a step gradient of $\mathrm{NaCl}$. The major peak of $\mathrm{C} 1 \mathrm{qR}$ activity was associated with the main protein peak. To obtain some insight into the size of $\mathrm{C} 1 \mathrm{qR}$, fractions $52-57$ were pooled, freeze dried and subjected to fractionation by HPLC on a TSK 3000 column. C1qR activity, associated with the only detectable protein peak, emerged from the column with an apparent molecular weight of $60 \mathrm{kDa}$. The fractions containing peak C1qR activity were pooled, freeze dried and part of it labelled with ${ }^{125} \mathrm{I}$ and analysed by SDS-PAGE and autoradiography. Under non-reducing conditions only one major band was seen with an apparent molecular weight of 55-62 kDa. Under reducing conditions the molecular weight was between 64-68 kDa (Fig. 3).

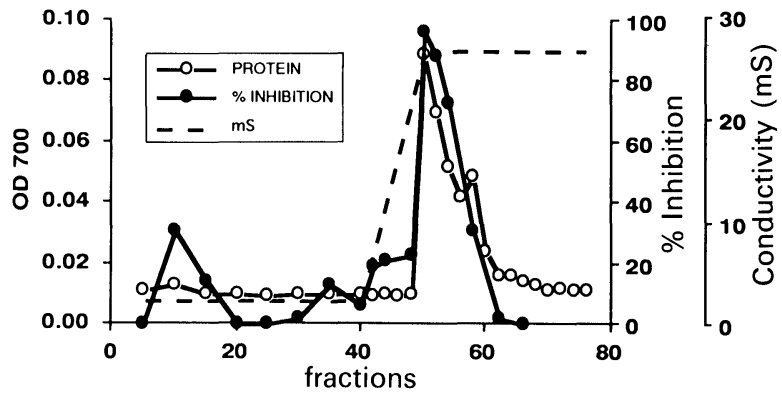

FIG. 2. Anion-exchange chromatography of affinity purified $\mathrm{C} 1 \mathrm{qR}$ on $\mathrm{OAE}-\mathrm{A} 50$. Protein content $(\mathrm{O}-\mathrm{O})$, conductivity $(--)$ and $\mathrm{C} 1 \mathrm{q}-\mathrm{R}$ activity (-) are shown. Fractions 52-57 were pooled for further analysis on TSK 3000-HPLC. 


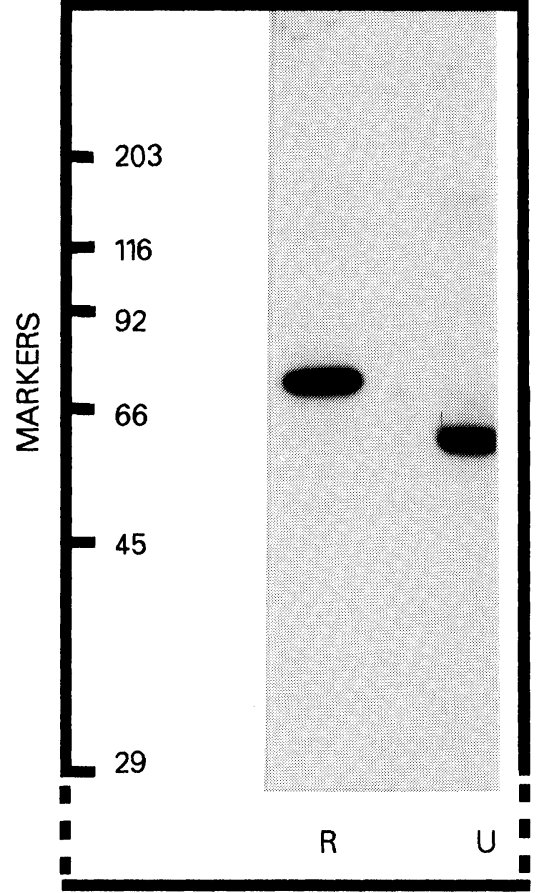

FIG. 3. SDS-PAGE of ${ }^{125}$ - $-\mathrm{C} 1 \mathrm{qR}$ under reducing $(\mathrm{R})$ and non-reducing (U) conditions

$\mathrm{C} 1 \mathrm{qR}$ was also isolated from the membranes of EAhy.926 using the same procedure as described above for HUVEC-C1qR. Comparable results were obtained concerning the size and functional activity of $\mathrm{C} 1 \mathrm{qR}$. Purified $\mathrm{C} 1 \mathrm{qR}$ isolated from either HUVEC or EAhy. 96 were both able to inhibit lysis of EAC1q in a dose-dependent manner (Table 1). $\mathrm{C} 1 \mathrm{qR}$ induces inhibition of lysis of EAC1q in $\mathrm{C} 1 \mathrm{q}$ deficient serum by binding to EAC1q and presumably by preventing the interaction with $\mathrm{C} 1 \mathrm{r}$ and $\mathrm{C} 1 \mathrm{~s}$ because EAC1q preincubated with $\mathrm{C} 1 \mathrm{qR}$, washed and subsequently exposed to C1q deficient serum at $37^{\circ} \mathrm{C}$ also exhibits inhibited lysis.

Monoclonal antibodies: Immunization of $\mathrm{BALB} / \mathrm{c}$ mice with purified HUVEC-C1qR and fusion of spleen cells with Sp2/0 hybridoma cells yielded two monoclonal cell lines, D5 and E3, both secreting $\operatorname{IgM}$. These two mAbs reacted only with $\mathrm{C} 1 \mathrm{qR}$ and not with $\mathrm{C} 1 \mathrm{q}$ or its fragments (Table 2). Western blot analysis revealed reactivity of D5 with one
Table 1. Inhibition of lysis of EAC1O by HUVEC C1OR and by C1OR isolated from EAHY926 cells

\begin{tabular}{lccc}
\hline & $\begin{array}{c}\text { Concentration } \\
\text { of } \mathrm{C} 1 \mathrm{qR} \\
(\mu \mathrm{g} / \mathrm{ml})\end{array}$ & $\begin{array}{c}\text { Lysis of EAC1q } \\
(\mathrm{Z})^{\mathrm{a}}\end{array}$ & \% Inhibition \\
\hline HUVEC & & & \\
& 0 & $1.31 \pm 0.11$ & - \\
& 5 & $0.83 \pm 0.10$ & 36 \\
EAHy926 & 10 & $0.36 \pm 0.09$ & 72 \\
& 20 & $0.15 \pm 0.06$ & 92 \\
& 5 & $0.96 \pm 0.11$ & 26 \\
& 10 & $0.41 \pm 0.08$ & 68 \\
& 20 & $0.20 \pm 0.06$ & 85 \\
\hline
\end{tabular}

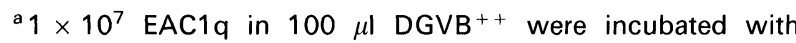
dilutions of $\mathrm{C} 1 \mathrm{qR}$ and $\mathrm{C} 1 \mathrm{q}$ deficient human for $60 \mathrm{~min}$ at $37^{\circ} \mathrm{C}$ and subsequently assessed for lysis. Percent inhibition was determined relative to EAC1 q lysis in C1 q deficient serum in the absence of $\mathrm{C} 1 \mathrm{qR}$

major molecule of approximately $60-64 \mathrm{kDa}$ in membrane lysates of both HUVEC and PMN (Fig. 4). In some experiments an additional faint band was seen at $96-98 \mathrm{kDa}$, but this band was also seen sometimes with isotype control $\mathrm{mAb}$. In addition some smaller molecular weight reaction products were seen around $45 \mathrm{kDa}$. Since the antigen used for immunization was purified by affinity chromatography over C1q-Sepharose we also tested whether D5 or E3 reacted with $\mathrm{C} 1 \mathrm{q}$, heat treated $\mathrm{C} 1 \mathrm{q}$, collagenous fragments of $\mathrm{C} 1 \mathrm{q}$ or heads of $\mathrm{C} 1 \mathrm{q}$. No significant reactivity of either $\mathrm{mAb}$ with $\mathrm{C1q}$ or its fragments was found by ELISA.

Effect of monoclonal antibodies against $\mathrm{C1qR}$ on $\mathrm{C1qR}$ mediated binding of ${ }^{125} \mathrm{I}-\mathrm{C} 1 \mathrm{q}$ : To determine whether the binding of ${ }^{125} \mathrm{I}-\mathrm{C} 1 \mathrm{q}$ to HUVEC could be influenced by $\mathrm{F}\left(\mathrm{ab}^{\prime}\right)_{2}$ fragments of $\mathrm{D} 5$, HUVEC monolayers of HUVEC were incubated with ${ }^{125} \mathrm{I}-\mathrm{C} 1 \mathrm{q}$ in the absence or presence of increasing concentrations of $\mathrm{mAb}$ (Table 3). While $37.2 \%$ of ${ }^{125} \mathrm{I}-\mathrm{C} 1 \mathrm{q}$ bound to HUVEC in medium alone, 20-200 $\mu \mathrm{g} \mathrm{F}\left(\mathrm{ab}^{\prime}\right)_{2}$ anti C1qR caused a dose-dependent inhibition of binding. Full inhibition of binding of ${ }^{125} \mathrm{I}-\mathrm{C} 1 \mathrm{q}$ was not observed in any of the three experiments performed.

Table 2. Reactivity of D5 and E3 with $\mathrm{C} 1 \mathrm{qR}$ or $\mathrm{C} 1 \mathrm{q}$ and its fragments ${ }^{\mathrm{a}}$

\begin{tabular}{lcccc}
\hline & \multicolumn{4}{c}{ Elisa wells coated with } \\
\cline { 2 - 5 } $\begin{array}{l}\text { Monoclonal } \\
\text { antibody }\end{array}$ & C1qR & C1q & C1q heads & C1q tails \\
\hline D5 & $2.23 \pm 0.14^{*}$ & $0.097 \pm 0.013$ & $0.099 \pm 0.014$ & $0.112 \pm 0.014$ \\
E3 & $1.78 \pm 0.18$ & $0.077 \pm 0.009$ & $0.087 \pm 0.007$ & $0.113 \pm 0.026$ \\
Isotype & $0.098 \pm 0.007$ & $0.093 \pm 0.012$ & $0.112 \pm 0.037$ & $0.088 \pm 0.041$ \\
control & & & & \\
\hline
\end{tabular}

a Elisa wells were coated with $1 \mu \mathrm{g} / \mathrm{ml}$ agent, washed and reacted with $\mathrm{mAbs}$ at a dilution of $1 / 500$ in triplicate. Washed and bound antibody was detected with goat antimouse lg-P0.

* Mean OD492 \pm 2 S.D. of of three wells. 


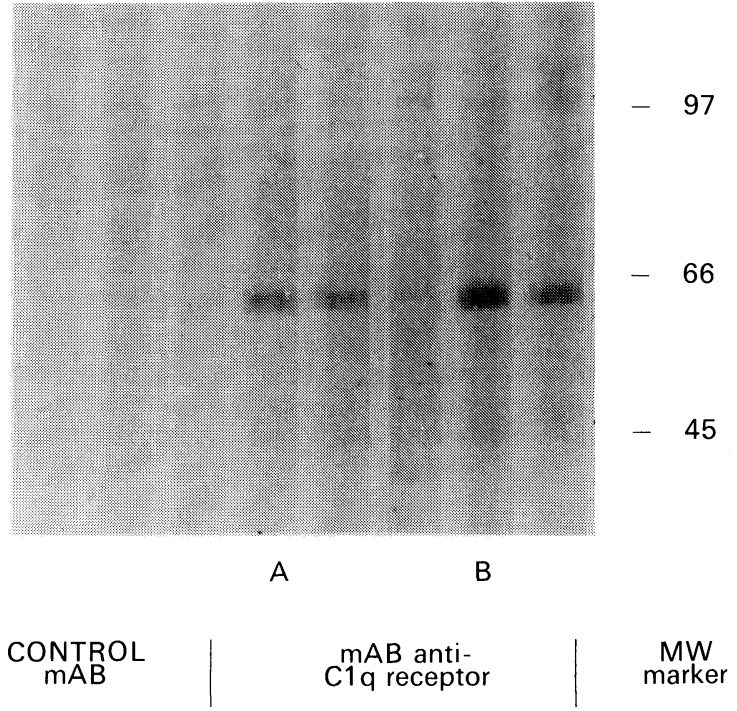

FIG. 4. Western blot analysis of monoclonal antibody against C1q-R. Five (left lanes) or $10 \mu \mathrm{g}$ lysates of endothelial cell membranes (A) or PMN membranes (B) were separated by electrophoresis, blotted onto nitrocellulose and analysed for reactivity with D5-anti-C1qR.

\section{Discussion}

The present study extends the previous observations $^{8}$ that human umbilical vein endothelial cells express a $\mathrm{C} 1 \mathrm{q}$ receptor that has identity or is closely related to $\mathrm{C} 1 \mathrm{qR}$ described on lymphocytes. ${ }^{9,10,14}$ $\mathrm{C} 1 \mathrm{qR}$ was isolated by affinity chromatography on C1q-Sepharose followed by further purification on QAE-A50 and TSK 3000-HPLC and detected during the isolation procedure using inhibition of lysis of EAC1q in $\mathrm{C} 1 \mathrm{q}$ deficient serum. The first step yielded material which was reasonably pure but minor contaminants were mainly removed in the QAE-A50 step. The purified C1qR filtered with an apparent molecular weight of $60 \mathrm{kDa}$ on TSK-3000. Although the molecular weights for lymphocyte $\mathrm{C} 1 \mathrm{qR}$ have been reported to be in the range from $56-70 \mathrm{kDa},{ }^{25}$ these differences probably reflect the different percentages of acrylamide used for SDS-PAGE.

Monoclonal antibodies against the purified endothelial cell $\mathrm{C} 1 \mathrm{qR}$ were raised. These monoclonal antibodies reacted with purified $\mathrm{C} 1 \mathrm{qR}$ from HUVEC and from EAhy.926 cells. The purified HUVEC C1qR was also shown to react with a polyclonal antibody (kindly donated by Dr R. B. Sim, Oxford) raised against the B-cell C1qR. On the other hand it was found that while the D5 mAb reacted also with B-cells and polymorphonuclear leukocytes $(\mathrm{PMN})$, the $\mathrm{E} 3 \mathrm{mAb}$ only reacts with $\mathrm{EC}$ and PMN and not with B-cells, suggesting differences in the epitopes of endothelial cell $\mathrm{C} 1 \mathrm{qR}$ and $\mathrm{B}$-cell $\mathrm{C} 1 \mathrm{qR}$. On the other hand $\mathrm{NH}_{2}$-terminal amino acid sequence analysis of the first fourteen amino acids did not show any differences with the
Table 3. Inhibition of binding of ${ }^{125} \mathrm{I}-\mathrm{C} 1 \mathrm{q}$ to endothelial cells by $\left.\mathrm{F}(\mathrm{ab})_{2}\right)_{2}$ anti-C1qR

\begin{tabular}{lcc}
\hline \multicolumn{1}{c}{ Reagent } & Percent bound & $\%$ Inhibition \\
\hline $125 \mathrm{I}-\mathrm{C} 1 \mathrm{q}$ & $37.2 \pm 4.8$ & - \\
$125 \mathrm{I}-\mathrm{C} 1 \mathrm{q}+20 \mu \mathrm{g}$ anti-C1 qR & $31.3 \pm 4.7$ & 16.9 \\
$125 \mathrm{I}-\mathrm{C} 1 \mathrm{q}+100 \mu \mathrm{g}$ anti-C1 qR & $21.4 \pm 5.1$ & 32.5 \\
$125 \mathrm{I}-\mathrm{C} 1 \mathrm{q}+200 \mu \mathrm{g}$ anti-C1 qR & $11.3 \pm 3.7$ & 69.3 \\
\hline
\end{tabular}

$10000 \mathrm{cpm}$ of ${ }^{125} \mathrm{I}-\mathrm{C} 1 \mathrm{q}$ were used per well.

recently reported sequence of $\mathrm{C} 1 \mathrm{qR} .{ }^{25}$ Further studies are needed to elucidate these differences. The D5 and E3 mAbs both recognized one major band in membrane lysates of both HUVEC and PMN. The size of C1qR from both these cell types was well within the reported range size of $\mathrm{C} 1 \mathrm{qR} .{ }^{26}$ While the D5 mAb was able to inhibit binding of ${ }^{125} \mathrm{I}-\mathrm{C} 1 \mathrm{q}$ to $\mathrm{EC}$ the $\mathrm{E} 3 \mathrm{mAb}$ was much weaker in this respect.

The results described in Table 1 indicate that endothelial cell $\mathrm{C} 1 \mathrm{qR}$ is able to interact with immune-complex-bound $\mathrm{C} 1 \mathrm{q}$ and prevent lysis of EA-C1q in C1q deficient serum, suggesting that assembly of an intact $\mathrm{C} 1$ on EAC1q is prevented. This mechanism may be of importance in vivo to regulate the degree of $\mathrm{C} 1$ activation in an early phase of the immune response. In addition during a primary immune response mainly IgM antibodies are generated. There are no known cellular 19S IgM receptors on human phagocytic cells, but by binding and activation of $\mathrm{C} 1$, and subsequent removal of activated $\mathrm{C} 1 \mathrm{r}$ and $\mathrm{C} 1 \mathrm{~s}$ from the IgM-immune complex-bound $\mathrm{C} 1 \mathrm{q}$, these types of immune complexes may be trapped very rapidly on vascular endothelial cells via C1qR, which, in turn, may ingest these complexes, and prevent further systemic immune complex-mediated inflammatory responses.

\section{References}

1. Van de Winkel JGJ, Anderson CL. Biology of human immunoglobulin G Fc receptors. J. Leukocyte Biol 1991; 49: 511.

2. Bogers WMJM, van Rooijen N, Janssen DJ, van Es LA, Daha MR Complement enhances the elimination of soluble aggregates of IgG by rat liver endothelial cells in vivo. Eur I Immunol 1993; 23: 433.

3. Cines DB, Lyss AP, Bina M, Corkey R, Kefalides NA, Friedman HM. Fc-and $\mathrm{C} 3$ receptors induced by Herpes simplex virus on cultured human endothelial cells. J Clin Invest 1982; 69: 123.

4. Para JF, Goldstein L, Speak PG. Similarities and differences in the Fc-binding glycoprotein ( $\mathrm{gE}$ ) of Herpes simplex virus types 1 and 2 and tentative mapping of the viral gene for this glycoprotein. J Virol 1982; 41: 137

5. Smiley ML, Hoxil JA, Friedman H. Herpes simplex virus type 1 infection of endothelial, epithelial and fibroblast cells induces a receptor for C3b. $J$ Immunol 1985; 134: 2673.

6. Linder E. Binding of $\mathrm{C} 1 \mathrm{q}$ and complement activation by vascular endothelium. J Immunol 1981; 126: 648 .

7. Andrews BS, Schadforth M, Cunningham P, David IV JS. Demonstration of a C1q receptor on the surface of human endothelial cells. J Immunol 1981; 127: 1075 .

8. Daha MR, Miltenburg AMM, Hiemstra PS, Klar-Mohammad N, van Es $\mathrm{LA}$, van Hinsbergh VWM. The complement subcomponent C1q mediates binding of immune complexes and aggregates to endothelial cells in vitro. Eur J Immunol 1988; 18: 783.

9. Tenner A. C1q interaction with cell surface receptors. Bebring Inst Mitt 1989; 84: 220 . 
10. Ghebrihiwet $\mathrm{B}$. Functions associated with the $\mathrm{C} 1 \mathrm{q}$ receptor. Bebring Inst Mitt 1989; 84: 204.

11. Erdei A, Reid KBM. Characterization of C1q binding material released from the membrane of Raji and U937 cells by limited proteolysis with trypsin Biochem J 1988; 255: 493

12. Malhotra R, Thiel S, Reid KBM, Sim RB. Human leukocyte C1q receptor binds on the soluble proteins with collagen domains. J Exp Med 1990; 172: 955.

13. Ghebrihiwet B. C1q receptor. Methods Enzymol 1987; 150: 558.

14. Malhotra R, Sim RB. Chemical and hydrodynamic characterization of the human leukocyte receptor for complement component C1q. Biochem J 1989; 262: 625 .

15. Erdei A, Reid KBM. The C1q receptor. Mol Immunol 1988; 1067.

16. Peerschke FIB, Ghebriwet B. Platelet $\mathrm{C} 1 \mathrm{q}$ receptor interactions with collagen- and C1q-coated surfaces. I Immunol 1990; 145: 2984.

17. Jaffe EA, Nachman RL, Becker CG, Minich CR. Culture of human endothelial cells derived from umbilical veirs. J Clin Invest 1973; 52: 2745.

18. Maciag T, Cerun dolo J, Isley S, Kelby PR, Bordwell C. An endothelial cel growth factor from bovine hypthalamus: identification and partia characterization. Proc Natl Acad Sci USA 1979; 76: 5674.

19. Edgell CS, MacDonald CC, Graham JB. Permanent cell line expressing human factor VIII-related antigen established by hybridization. Proc Nat Acad Sci USA 1983; 80: 3734.

20. Daha MR, Klar N, Hoekzema R, van Es LA. Enhanced Ig production by human peripheral lymphocytes induced by aggregates. J Immunol 1990; 144: 1227.
21. Thorell JL, Larson I. Lactoperoxidase coupled to polyacrylamide for radio-iodination of proteins to high specific activity. Immunochemistry 1974 224: 203

22. Böyum A. Isolation of leukocytes from human blood. Furthe observations: methyl cellulose, dextran and ficoll as erythrocyte aggregating agents. Scand J Clin Lab Invest 1968; 21 Suppl 97: 77.

23. Laemmli UK. Cleavage of the structural proteins during the assembly of the head of bacteriophage T4. Nature (Lond.) 1970; 227: 680.

24. Van der Zee JM, Heurkens AHM, van der Voort EAM, Daha MR, Breedveld FC. Characterization of anti-endothelial antibodies in patients with rheumatoid arithritis complicated by vasculitis. Clin Exp Rheumatol 1991; 9: 589

25. Peerschke EIB, Malhotra R, Ghebrehiwet B, Reid KBM, Willis AC, Sim RB. Isolation of a human endothelial cell C1q receptor. J Leuk Biol 1993 53: 179 .

26. Malhotra R, Willis AC, Jensenius JC, Jackson J, Sim RB. Structure and homology of human C1q receptor (collectin receptor). Immunology 1993; 78. $341: 348$.

ACKNOWLEDGEMENT. The authors thank Evert Heemskerk for the isolation of $\mathrm{C} 1 \mathrm{q}$.

\section{Received 18 August 1993;}

accepted 7 October 1993 


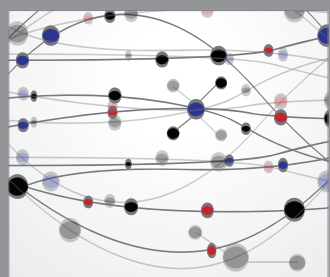

The Scientific World Journal
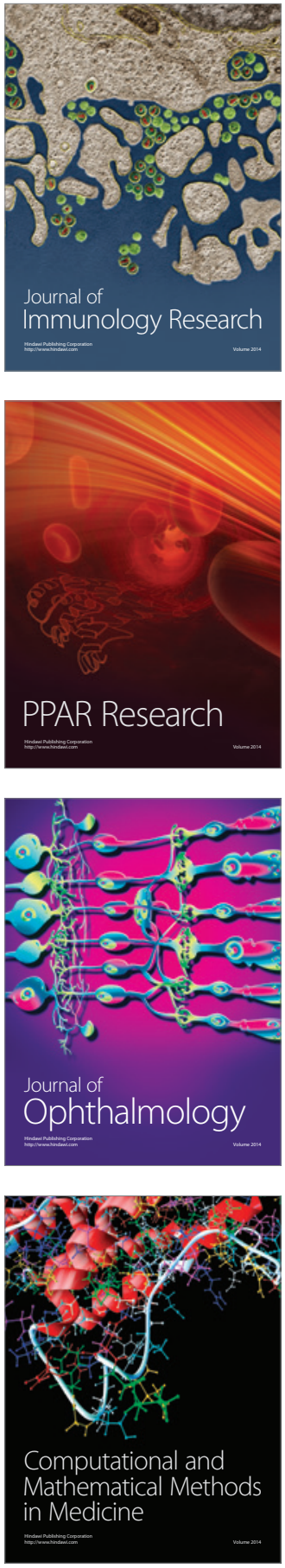

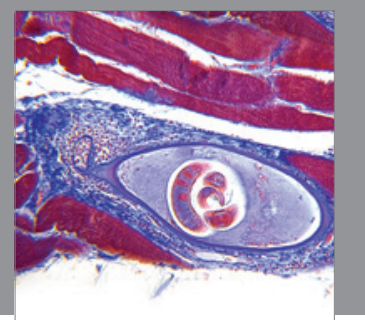

Gastroenterology

Research and Practice
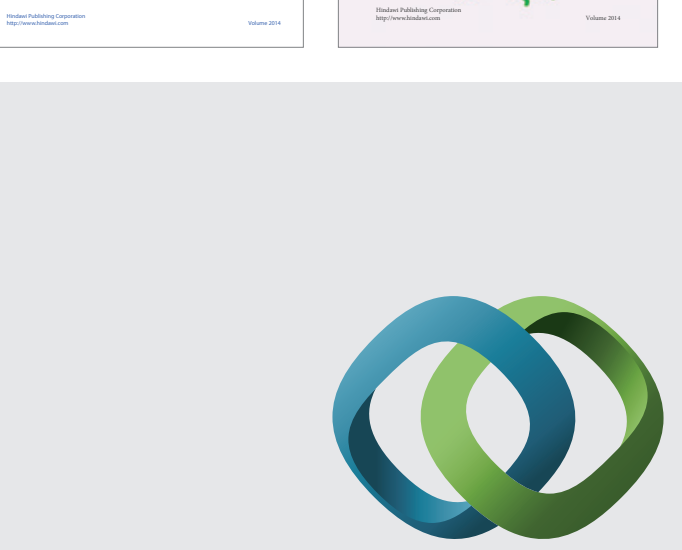

\section{Hindawi}

Submit your manuscripts at

http://www.hindawi.com
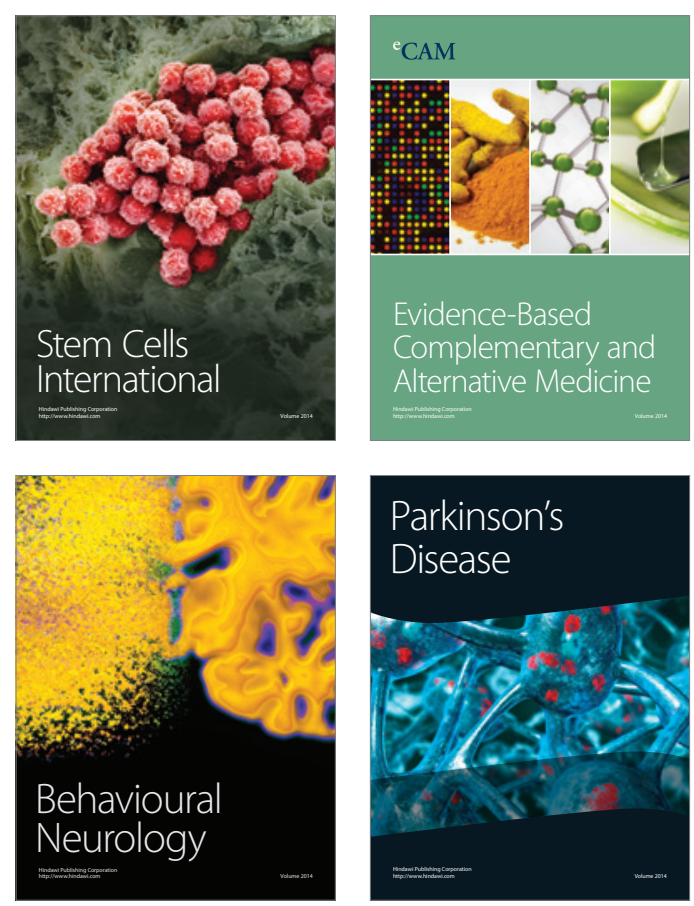

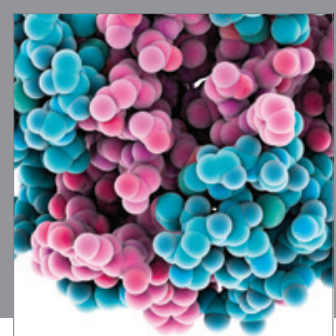

Journal of
Diabetes Research

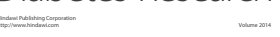

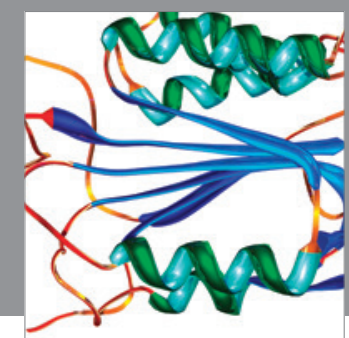

Disease Markers
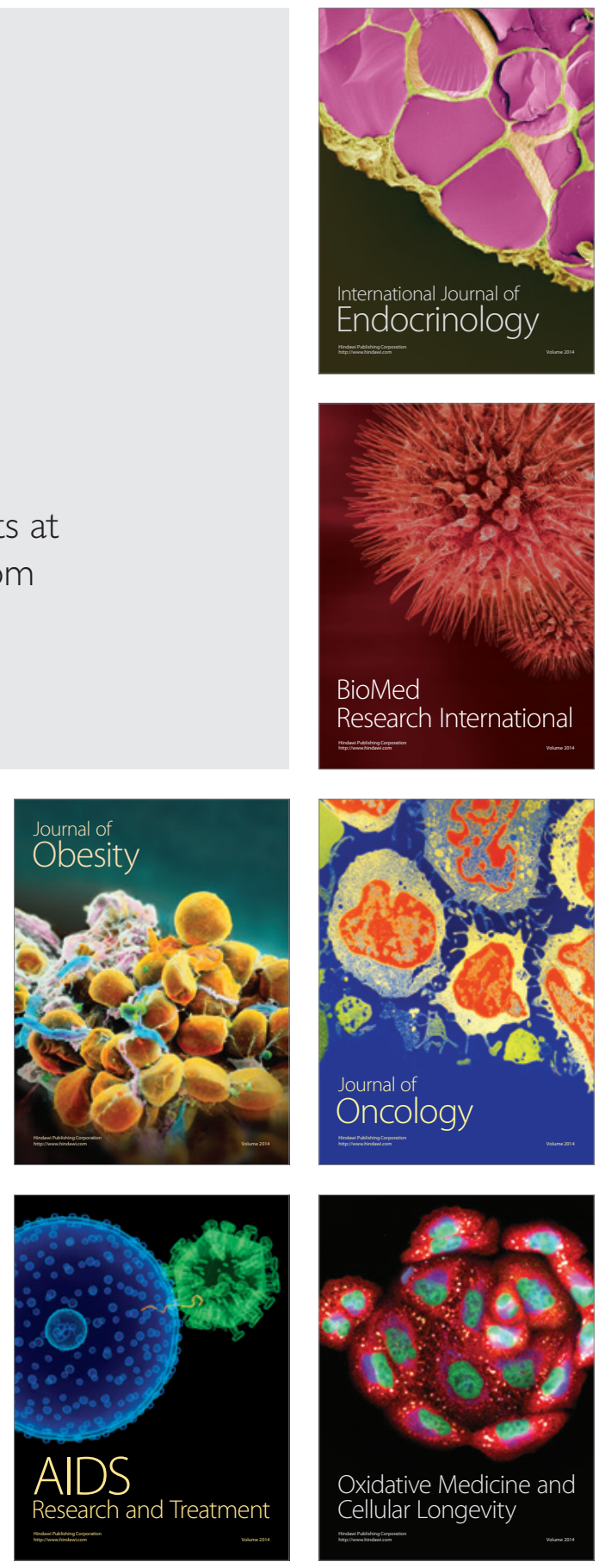